\title{
Is Permitting Student Use of Laptops in Class a Good Idea?'It Depends' - A Variety of Approaches is Best
}

Lynn McLain

University of Baltimore, Imclain@ubalt.edu

Follow this and additional works at: http://scholarworks.law.ubalt.edu/all_fac

Part of the Legal Education Commons

\section{Recommended Citation}

Lynn McLain, Is Permitting Student Use of Laptops in Class a Good Idea? 'It Depends' - A Variety of Approaches is Best, (2009).

Available at: http://scholarworks.law.ubalt.edu/all_fac/927

This Article is brought to you for free and open access by the Faculty Scholarship at ScholarWorks@University of Baltimore School of Law. It has been accepted for inclusion in All Faculty Scholarship by an authorized administrator of ScholarWorks@University of Baltimore School of Law. For more

information, please contact snolan@ubalt.edu. 


\title{
Is Permitting Student Use of Laptops in Class a Good Idea? "It Depends": A Variety of Approaches is Best
}

\author{
Lynn McLain \\ February 17, 2009
}

\section{A Sampling of Sources Discussing Students' Use of Technology in the Classroom}

- David L.C. Thomson, Law School 2.0 (Lexis Nexis 2008) (prof. at Univ. of Denver, director of Lawyering Process program) (how to use technology to prepare our students "for their future, not our past"). This book argues for wide-ranging changes from legal education as-we-experienced-it: more practice-oriented exercises; more collaborative work among students (as Mike Schwartz suggested); fewer in-class meetings; pod-casts of those sessions; video recordings of professors explaining complex issues, etc.

- LSSSE 2008 Report, Student Engagement in Law Schools: Preparing 21 st Century Lawyers (may be obtained for $\$ 10$ from the LSSSE Web site, http://lssse.iub.edu) (national study released in January 2007 by Indiana University reportedly found that law students who frequently used their laptops to take notes, review ideas from past lectures or read a self-prepared case brief were more likely to come to class prepared, contribute to class discussions synthesize material across courses, and work hard to meet faculty expectations"). (George Kuh, prof. at Indiana Univ., is director of LSSSE) (article found by Audrey McFarlane).

- Jill Schachner Chanen, Profs. Kibosh Students' Laptops, A.B.A.J. 16 (Nov. 2007) (Prof. Kate Nace Day at Suffolk, enough Duke profs. that school dropped requirement that students have laptops).

- Joanne Ingham \& Robin A. Boyle, Generation X in Law School: How Those Law Students Are Different from Those Who Teach Them, 56 J. LEGAL ED. 281 -95 (June 2006) (Gen-X'ers learn best by doing; multi-sensory and interactive techniques are most effective).

- Richard K. Sherwin, Neal Fergenson, Christina Spiesel, Law in the Digital Age: How Visual Communication Technologies are Transforming the Practice, Theory, and Teaching of Law, 12 BosTon U. J. SCI. \& TECH. L. 227-270 (Summer 2006) (having students draw digital pictures rather than word pictures).

- Kevin Yamamato, Banning Laptops in the Classroom: Is it Worth the Hassles?, $57 \mathrm{~J}$. LEGAL ED. 477-515 (Dec. 2007) (tax prof. at S. Texas: reports on "cognitive science of learning and memory, and his and his students' largely positive experiences with his banning laptops).

- Roger Park, U.C. Hastings, students" use of hand-held "clickers" from the Turning Point Co. to vote on answers to questions posed on Power Point slides. 


\section{Anecdotal Information}

My experience: 3 courses; permitting laptops in 2 of 3 this academic year. In fall $2008 \mathrm{I}$ experimented in the other, Evidence, with no laptops (except as required by ADA: one paid ADA note taker for ADA students, plus ADA students themselves, at their option ${ }^{1}$ ) for in-class note-taking. This is a course in which very few notes need be taken in class: the "lecture" material, as well as problems and cases, is in the text I have written for my students. Classtime is focused on discussion of problems and pre-divulged questions. (Laptops were permitted for homework, post-class synthesis, for midterm and final exams, and in class for recording class.)

- Ban suggested by some top 2007 Evidence students in spring 2008.

- My decision to experiment was buoyed by experiences visiting others' classes, by student reports of distraction by fellow students' watching movies (in other classes), and by apparently diligent students' responses, "Could you repeat the question? I was typing.")

- Notice and rationale sent out to 106 students (79 in Day, 27 in Evening) in June 2008.

- One student came to see me. He e-mailed all others via TWEN, after we talked, as to how his concerns were assuaged.

- A second student sent the following e-mail in July:

As for the laptop policy. For one, I am (started) writing this e-mail while in class. Laptops while in class are extremely tempting distractions. Laptops are an endless source of distraction, or just temptation for distraction.

I see laptops as no different than cell phones in class. They are a great improvement in quality of life, but bring with them ever evolving questions of social appropriateness. Answering an e-mail in class may be less distracting than answering a phone call in class, but is nonetheless a distraction to all. Given the professional training of the school, quality and depth of knowledge of graduates reflects immediately upon the school. Those that spend more time browsing the Internet than browsing their own mind to ensure understanding adversely affect more than just the student. The Socratic method demands immediate and continuous involvement with ever evolving questions. Students that are not paying attention adversely affect those in the class with statements such as "can you repeat the question" and "I'm sorry I didn't 'understand' your question." It is really not difficult to tell that someone was not paying attention after they are called on, and it slows class to a crawl for those that were paying attention. While it is true that wrong answers can be as beneficial as right answers, "wrong" answers may reflect a different way of interpretation, highlight a point easily confused or help instructors clarify material. Uninformed inattentive answers that do not conform with freshly discussed and clarified material are detrimental. Those that dedicate more brainpower to transcription of the class than any participation rob other students of a classmate's alternate point of view and

1 I posted these notes on TWEN for Jewish holidays and e-mailed them to specific students who had absences for Muslim holidays or other sound reasons for missing class. If I did not have an ADA note-taker, I think I would follow Rich Friedman of Michigan's approach of having one student per day take laptop notes for the class and e-mail them to the others. 
often interrupt by having instructors repeat minute statements.

Alternately, a closed laptop policy does potentially have an adverse effect on creation of an outline and synthesis of material. Many materials are quickly and easily accessed by Internet, including rules and cases, with one-click access. However, in my opinion, if an instructor feels that students learning their material would be better served by pen, paper, highlighter or abacus, then that should be within the professional discretion of the instructor. Again, comprehension and application of key courses involving critical complex material reflect upon not only the student, but directly upon the instructor and the school. Whether an instructor believes laptops to be a distraction, a learning impediment, or any combination thereof, the appropriate course of action should be taken by the instructor, and I trust a professional educator to make decisions in the interests of the class and individual students.

Basically, I personally find laptops more of a distraction than a benefit; institutionally I see laptops becoming an increasing impediment to class flow and learning and thus appropriately within the discretion of instructors. Granted, $\mathrm{I}$ am a rising $2 \mathrm{~L}$ and have nothing beyond personal opinions and observations to support my views, but I hope my input has some benefit nonetheless.

- No students dropped the class because of the experiment. One was forced to drop because of academic probation, and one transfer dropped because he wasn't "getting" hearsay.

- I asked that the students try working in class without open laptops for the first few weeks, and promised I would check in with them to see how they felt it was working.

- My observations: class participation and dialogue were significantly stronger than when there was a sea of laptops.

- I e-mailed the students on September 2, 2008, to "take their temperature." The 29 responses to that question, by reply e-mails, can be categorized into four groups, from largest to smallest, as follows:

(1) Like the policy in this class, but think it works better in this course than it would in others: 15 responses

E.g.

- The "ban on laptops" in Evidence has been appropriate for your class, and it has helped me concentrate on learning a very difficult subject.

$\sim \quad$ Surprisingly, I am enjoying not having laptops. I find that I am less distracted and can follow along much more closely without my laptop. Your teaching style also helps to keep me engaged. As an added bonus, I have one less heavy bag I have to lug around.

- In response to the "no computer rule," I find it very appropriate for our evidence class. As you mentioned before, if prepared for class, there will not be a huge need to take notes. I have found this to be very true. I think it is very helpful for class discussions. However, I think it would not work with a typical class format, as the need for taking specific/clear notes might warrant the use of a laptop. In our class, although before class 
started it stressed me out, I have found that it hasn't caused any problems for me. I think that it has promoted more of my class participation.

Like the no lap-top classroom: am adopting it voluntarily in my other classes or wish other classes had ban: 11 responses

E.g. :

- I am very happy with the no lap-top policy. I don't use it anymore in any of my classes and I've found myself focusing and distilling my notes, as opposed to trying to blindly type everything out. I feel like I get more out of the class, and more vigilant with how I approach the class in general.

I am very happy with the laptop policy. It is my opinion that most learning in law school is done while thinking, not writing.

- I personally am in favor of the no laptop in class rooms rule. From a student's perspective, other students' laptops can become very distracting. This week alone, I have been distracted by classmates looking at dozens of pool party pictures and another classmate watching baseball during the lecture while chatting with 5 different people. Personally, I feel it's refreshing not to have laptops in the classroom.

- I hate to admit it, but the no-laptop policy is wonderful. Class time flies by and I don't get distracted the way that I do in other classes. I'm more awake in your class than I am in my earlier class (with laptops). So here's one vote "for" the new rule.

$\sim \quad$ Not using my laptop has been great! I've actually stopped using it for my other classes. I find that I concentrate better because the temptation to get on the internet just isn't there. Also, I feel like I retain the information better when I write it down opposed to when I type it.

Don't like the ban: more work to print out homework before class: 2 responses

\section{The more outspoken of these 2 students wrote:}

To be honest, I don't love it. I don't mind Evidence being the only class for which I don't use a laptop during class. But because I much prefer to outline, study and do problems@ home on my laptop, Evidence has required me to adjust my at-home study practices and I'm not sure I'll be able to get used to it in time to perform well on the midterm. It feels like double-work to do my class preparation on the computer and then bring hard copies of my electronic work product to class with me.

(4) I don't use laptops in class, but feel that students who do surf the internet are only hurting themselves, and that should be their choice: 1 response

Just as background of my general study habits for classes: usually I will handwrite my notes for class, then I will synthesize those notes onto a typed outline toward the end of the semester, lastly, if I think it will be helpful I will synthesize my notes further onto note cards (I will only make flashcards if the class is "rule" heavy, ex. criminal law, con law, etc., otherwise I don't find note cards too helpful). 
I prefer to handwrite my notes for two reasons:

(1) I can type a lot faster than I write. If I typed my notes in class I could probably copy everything said. By writing slower I am forced to make a determination of what is important and what I need to "pull" from the info. for later and write only that down. This determination is easier to make in class, real time, for several reasons. It could be the express instructions of the professor, the professor's tone, or some other harder to identify factor apparent at the time. Looking at a copy of everything said during class, after the fact, makes it much harder to identify what material to focus on when I begin review.

For me, the key to (moderate) success in law school has been the ability to digest (at least partly) massive amounts of complicated information. This process begins with focused note taking and requires the ability to constantly whittle away at secondary information and to really focus on the main points. I begin the identification of what is primary info and what is "side" info in class when I determine what info is necessary to take down. Once I begin to have a firmer grasp of the main points it becomes easier to recognize/understand/memorize/apply the smaller, secondary points which stem from the more general and more important points. Even in situations where I have forgotten some more specific information, at least on an exam I will be able to provide an answer which shows a basic understanding of the general concepts the professor is testing. As we are told before most exams, something is better than nothing.

(2) Quite frankly, it keeps me from surfing the internet when I start to lose focus in class.

But in my opinion laptops are fine in class as long as they are used exclusively to take notes. I think some people really are better off using laptops for whatever reason. The issue is that many students use laptops to surf the internet and the rules regarding internet use during class aren't really taken too seriously (at least from what I have seen). I think the school has three alternatives to "improve" classroom discussion: (1) ban laptop use; (2) enforce existing rules regarding internet use in the classroom; or, (3) find some way to restrict internet use in the classroom (create a kind of internet "dead zone" if possible) Not sure what the best alternative would be.

On the other hand, I think there is a strong argument for leaving things the way that they are (my personal choice). If a student decides that he or she would rather be on the internet during class, so be it. That student is only hurting themselves, so why should anyone other than that person be concerned? Kind of harsh, but makes some sense to me. I know this is probably not the best alternative from an educator's point of view. However, banning laptop use hurts those who benefit from using their computers. Enforcing existing rules means that someone is going to be put in front of the Honor Commission (a very serious blemish on their record) for breaking a rule that is broken all the time. Enforcing the rule against the unfortunate offender would seem arbitrary and unfair given the lax enforcement up until that point. Restricting internet use almost makes it seem like middle school. Shouldn't law students be able to control themselves enough to stay off the internet without the school having to create a "dead zone"? Tough question, glad I don't have to decide it. 